\title{
ДВУГЛАВЫЙ ОРЕЛ В СОВРЕМЕННОЙ УЧЕБНО-МЕТОДИЧЕСКОЙ ЛИТЕРАТУРЕ РОССИИ
}

\section{DOUBLE-HEADED EAGLE IN MODERN EDUCATION AND METHODICAL LITERATURE OF RUSSIA}

\section{A. Demidov}

Summary: The article provides a comprehensive, comprehensive analysis of modern educational and methodological literature in Russia devoted to the double-headed eagle. The main trends in the reflection of the topic in textbooks of the 1990s-2010s are identified. The advantages and disadvantages of studying the history of the double - headed eagle in the educational process in higher and secondary educational institutions are Listed. The conclusion is made about the formation of purposeful attention to this symbol in modern educational and methodical literature, and its role in the Patriotic education of students is shown.

Keywords: double-headed eagle, heraldry, state symbols, educational and methodical literature, historiography.
И 3 всех аспектов геральдики в современном российском образовании наибольшее внимание уделяется государственной символике, в частности ее происхождению и идеологическому значению, что реализуется в необходимости формирования у учащихся устойчивых представлений об истории основного ее элемента - двуглавого орла [изложение основных проблем, связанных с его изучением см.: 17].

Изучение истории этой эмблемы в образовательных учреждениях России имеет давнюю традицию, которая начала формироваться еще в XVIII в. [подробнее см.: 18, с. 114-115]. В лекциях Ю.В. Арсеньева [1], изданных в 1908 г., российский двуглавый орел упоминался кратко, поскольку учебный курс был ориентирован на западный геральдический опыт. В советский период, с начала 1930х гг., сведения о государственной символике императорской России были перенесены из раздела геральдики в лекции по сфрагистике и рассматривались в контексте истории государственной печати. Там они казались более обусловленными фактическим материалом и идеологически безопасными. Так поступил в своем курсе в Историко-архивном институте известный архивист Н.П. Чулков, а вслед за ним Н.В. Устюгов, Е.И. Каменцева, Г.А. Леонтьева $[9,10,11,24]$. Эта традиция удерживалась до середины 1990-х гг. Даже в учебнике по специальным историческим дисциплинам, изданном в 1994 г., история государственного герба подменялась историей государственной печати и неоправданно соединялась с
Демидов Анатолий Игоревич

Аспирант, Московский Государственный Областной Университет demidoff2416@gmail.com

Аннотация: В статье выполнен всесторонний, комплексный анализ современной учебно-методической литературы России, которая касается истории основного государственного символа - двуглавого орла. Выявлены основные тенденции в отражении темы учебными пособиями 1990-х - 2010-х гг. Перечислены достоинства и недостатки в изучении истории двуглавого орла в образовательном процессе в высших и средних учебных заведениях. Сделан вывод о формировании целенаправленного внимания к этому символу в современной учебно-методической литературе, показана его роль в патриотическом воспитании учащихся.

Ключевые слова: двуглавый орел, геральдика, государственная символика, учебно-методическая литература, историография.

изложением эволюции территориальной геральдики России; причем в совокупности этому была посвящена всего одна страница текста, а вопрос о происхождении двуглавого орла, его значении и эволюции был обойден полным молчанием [12, с 168-169], только в переизданиях начала XXI в. ситуация стала исправляться и раздел дополнился необходимой информацией [16].

В период перестройки с характерным для нее стремлением к переосмыслению прошлого, а особенно после 1993 г., когда двуглавый орел стал государственным гербом Российской Федерации, ситуация кардинальным образом изменилась. Двуглавый орел стал не только объектом пристального исследовательского интереса и популяризации, но и занял видное место в учебном процессе, причем не только в высших учебных заведениях, но также в среднем образовании. Соответствующие разделы стали обязательными в учебниках по геральдике и специальным историческим дисциплинам. В пособиях, предназначенных для школ, эта тема рассматривалась, как правило, вместе с историей государственного флага и государственного гимна Российской Федерации [3, 22 и др.]. Тексты ориентировались на учащихся различных возрастов, для каждой возрастной группы разрабатывалось свое учебно-методическое обеспечение темы. В 1990-х гг. сведения о двуглавом орле в пособиях, предназначенных для средних учебных заведений, были во многом поверхностными, содержали случайные факты и часто заимствовались из устаревшей историографии 
императорского периода, из энциклопедических изданий и не учитывали результаты новейших специальных исследований.

Внимание к государственной символике и, следовательно, к двуглавому орлу, увеличилось в пособиях с 2000-х гг., когда официально была отмечена необходимость патриотического воспитания молодежи, в том числе - формирование уважения к государственным символам страны. С того момента стали появляться учебники не только об истории государственных символов, но и посвященные исключительно российскому гербу. Эволюция двуглавого орла занимала в них одно из основных мест. Информационно-методический уровень этой литературы оказался различным, что во многом было обусловлено тем, что среди авторов оказались как профессиональные историки, в том числе специалисты по геральдике, так и педагоги, не обладавшие специальными знаниями. Появилось несколько удачных пособий для средних учебных заведений, выдержавших несколько переизданий. Их авторами являлись известные специалисты по символике - доктора исторических наук Н.А. Соболева и А.Л. Хорошкевич, кандидат исторических наук М.П. Голованова, кандидат философских наук Г.В. Ражнев и др. [2, 4, 20, 23, 25]. Следует также отметить раздел по истории государственной символики в несколько раз переиздававшемся учебнике по геральдике доктора исторических наук А.А. Корникова, его содержание отличается взвешенность теоретических подходов и строгой научностью изложения $[13,14]$. В названных текстах обстоятельно и всесторонне изложена история государственных символов России - герба, флага и гимна; фактический материал транслируется на высоком научном уровне, с учетом последних достижений отечественной историографии; даются альтернативные трактовки принципиальных для понимания темы сюэетов (например, о происхождении российского двуглавого орла).

Наиболее сложным вопросом при изучении двуглавого орла в образовании является проблема его генезиса. Благодаря исследованиям В.А. Кучкина в настоящее время полностью отвергнута теория Н.М. Карамзина о византийском происхождении символа [15]. Она сводилась к тому, что государственная эмблема была заимствована из Византии благодаря браку великого князя московского Ивана III с Софьей Палеолог, она должна была выражать перемещение центра православия из Константинополя в Москву (теория «Москва - Третий Рим»). На самом деле двуглавый орел был заимствован с герба Священной Римской империи в 1490 г. и выражал претензии Ивана III на императорский статус [подробнее см.: 15, 17]. Однако в учебно-методической литературе, особенно предназначенной для школ, продолжает упоминаться как единственно правильная версия о византийском происхождении. Причем этот вопрос входит в состав знаний, необходимых для сдачи ЕГЭ, и, естественно, с ошибочным ответом, который считается правильным. Такая ситуация обусловлена тем, что византийская версия глубоко укоренилась в массовом сознании и в большей степени соответствует идеологическим трендам современности, чем более исторически достоверная германская. В некоторых пособиях (предназначенных для высших учебных заведений или написанных специалистами) упоминается и о ней, но не всегда отмечается ее познавательный приоритет.

В школьной учебно-методической литературе имеются примеры еще более невежественных трактовок вопроса о происхождении двуглавого орла. Например, в несколько раз переизданном пособии Е.К. Ривиной утверждалось, что «гербом Тверского княжества в то время (в XV в.) было изображение двуглавого орда», и что он сыграл заметную роль в том, что эмблемой Русского централизованного государства стал этот мифический персонаж. Автор подтверждала свое ложное утверждение таким «аргументом»: «Ведь неслучайно, наверно, главная улица в столице нашей Родины Москве носит название Тверской» [21, с. 45]. Версия о тверском происхождении двуглавого орла высказывалась нумизматом А.В. Орешниковым в конце XIX в., но давно опровергнута, а название Тверской улицы никакого отношения к выбору государственной эмблемы не имело. Подобные учебные пособия могут создать у учащихся неправильное представление об истоках российской государственной символики.

Сравнительно быстро, уже в середине 1990-х гг. сформировалось методическое обеспечение преподавания государственной символики. Были опубликованы программы курсов в высших учебных заведениях, методические разделы имелись в учебных пособиях для средних образовательных учреждений. В литературе [7] предлагалось около 30 вариантов ознакомления с отечественной государственной символикой (и историей двуглавого орла) для школьников. Среди них аукцион знаний «Из истории символов», бюро вопросов и ответов, вечер актуальных проблем (диспут), день интервью, диалог «Два взгляда», пресс-бой, устный журнал «Символы нашей Родины», викторина «О чем рассказывает наш герб», конкурс эрудитов, познавательная олимпиада, конкурс книжных новинок, турнир ораторов, конкурс рисунков, ярмарка солидарности, вечер-презентация государственных символов России и, вполне в духе постперестроечного времени, программа «Взгляд». Целенаправленно раскрывалась в учебно-методических пособиях методика проведения основных способов ознакомления с государственным символом - беседы, классного часа, диспута, турнира-викторины, а также приводилась тематика занятий в кружке по геральдике. Много лет проводятся всероссийские конкурсы для учащихся на знание истории государственной символики, 
на них вопрос об эволюции двуглавого орла привлекает неизменное внимание, а лучшие работы учащихся по этой проблеме публикуются в специальных сборниках [19].

Для учащихся 10 - 11 классов в пособиях предлагалось обсуждать сложные вопросы, предполагающие знание альтернативных трактовок - например, версии о происхождении двуглавого орла. К числу проблемных авторы относили также вопрос о влиянии Византии и, особенно, православия на государственную символику России.

В последние годы в историографии отмечается стремление ознакомить с историей государственной символики все возрасты учащихся, включая начальные классы [5], а также дошкольников. В данном контексте можно отметить появление издания для детей, начиная с 3 лет $[6,8]$.

Таким образом, в современной учебно-методической литературе сформировался дифференцированный подход к изучению истории двуглавого орла в широком контексте ознакомления с историей государственной символики в целом.

Долгое время слабой стороной ознакомления с государственной символикой являлось обеспечение процесса наглядными материалами. Иллюстрации в пособиях были блеклыми, черно-белыми, а иногда и отсутствовали. В настоящее время, благодаря Интернету и ряду специализированных изданий [8] проблема эта в целом решена.

Следует отметить, что успешное развитие современной учебно-методической литературы, связанной с государственной символикой России, преподавания геральдики в целом, широкое и последовательное внедрение его в среднее образование происходили на основе решений правительства РФ о патриотическом воспитании молодежи. В них формулировалась необходимость знания учащимися символики Российского государства, ее истории.

К настоящему времени учебно-методическая литература, раскрывающая историю государственных символов России и в том числе происхождение, иконографическую и семантическую эволюцию двуглавого орла, представляет собой обширный и сложный комплекс самых разнообразных пособий, предназначенных для всех возрастов детей и молодежи и для образовательных учреждений различного статуса. Эти публикации являются неотъемлемой частью геральдической историографии современной России, тесно связаны с ней информационно, отражают этапы ее познавательной эволюции.

\section{ЛИТЕРАТУРА}

1. Арсеньев Ю.В. Геральдика. Лекции, читанные в Московском археологическом институте в 1907/1908 г. М.: Печатня А.И. Снегиревой, 1908. IV, 298 с.: ил.

2. Беркс П.М., Ражнев Г.В. Герб России: развитие символики. Смоленск: Изд-во «Смоленская городская типография», 2006. 127 с.: ил.

3. Гамаль Е.В. Герб, флаг и гимн России: Методические рекомендации для учителей средних классов и специалистов по воспитательной работе в школе. Ростов-на-Дону, 2007.77 с.

4. Голованова М.П., Шергин В.С. Государственные символы России: Научно-поп. изд. для детей. М.: 000 «Изд-во «Росмэн-пресс»», 2003. 159 с.: ил.

5. Государственные символы России: герб, гимн, флаг: в помощь учителю начальных классов / сост. Т.В. Шепелева. 3-е изд., перераб. М.: 000 Учитель, 2019. 69 c.

6. Государственные символы Российской Федерации: наглядно-дидактическое пособие: 3 - 7 лет. М.: Мозаика-Синтез, 2017.

7. Государственные символы Российской Федерации: Методические рекомендации в помощь учителям и воспитателям образовательных учреждений. Курган: Курганский ИПКРО, 1996. 51 с.: ил.

8. Калашников Г.В. Гербы и символы: история российского герба: альбом демонстрационных картин для детей 5-7 лет. М.: Детство-пресс, 2019. 32 с.

9. Каменцева Е.И., Устюгов Н.В. Русская сфрагистика и геральдика:Учебное пособие. М.: Высш. школа, 1963. 224 с.: ил.

10. Каменцева Е.И., Устюгов Н.В. Русская сфрагистика и геральдика: Учебное пособие. 2-е изд., доп. М.: Высш. школа, 1974. 264 с.: ил.

11. Кобрин В.Б., Леонтьева Г.А., Шорин П.А. Вспомогательные исторические дисциплины: Учебное пособие. М.: Просвещение, 1984. 208 с.: ил.

12. Кобрин В.Б., Леонтьева Г.А., Шорин П.А. Ключи к тайнам Клио: Кн. для учащихся. М.: Просвещение, 1994. 286 с.: ил.

13. Корников А.А. Основы российской геральдики: Курс лекций. Иваново: Изд-во Ивановского гос. ун-та, 2004. 219 с.: ил.

14. Корников А.А. Основы российской геральдики: Курс лекций. Ч.1. Иваново: Изд-во Ивановского гос. ун-та, 2001. 107 с.: ил.

15. Кучкин В.А. Великокняжеская печать с двуглавым орлом грамоты 1497 года // Вопросы истории. 1999. № 4/5. С. 24-39.

16. Леонтьева Г.А., Шорин П.А., Кобрин В.Б. Вспомогательные исторические дисциплины: учебник. М.: Владос, 2015. 343 с.: ил.

17. Наумов О.Н. Государственный герб России как проблема исторического знания // Преподавание истории в школе. 2009. № 5. С. 3-8.

18. Наумов 0.Н. Научная геральдика России. М.: Старая Басманная, 2013. 508 с.

19. «0веянные славою флаг наш и герб»: Сборник работ лауреатов Всероссийского творческого конкурса, посвященного истории государственной символики РФ. М., 2003. 160 c.

20. Пчелов Е.В. Государственные символы России. Герб, флаг, гимн: Учебное пособие. М.: Русское слово, 2002. 135 с.: ил. 
21. Ривина Е.К. Государственная символика России: Беседы в начальной школе. М.: ТЦ Сфера, 2006. 60 с.: ил.

22. Серов Б.Н. Поурочные разработки по курсу «Государственная символика» Гимн. Герб. Флаг. М.: ВАКО, 2005. 190 с.

23. Соболева Н.А. Российская государственная символика: история и современность: Учебное пособие. М.: ВЛАДОС, 2002. 207 с.: ил.

24. Устюгов Н.В. Учебное пособие по вспомогательным историческим дисциплинам. Ч. 4. М., 1940. 25 с.: ил.

25. Хорошкевич А.Л. Герб, флаг и гимн: Из истории государственных символов Руси и России. М.: Время, 2008. 190 с.: ил.

(с Демидов Анатолий Игоревич (demidoff2416@gmail.com)

Журнал «Современная наука: актуальные проблемы теории и практики»

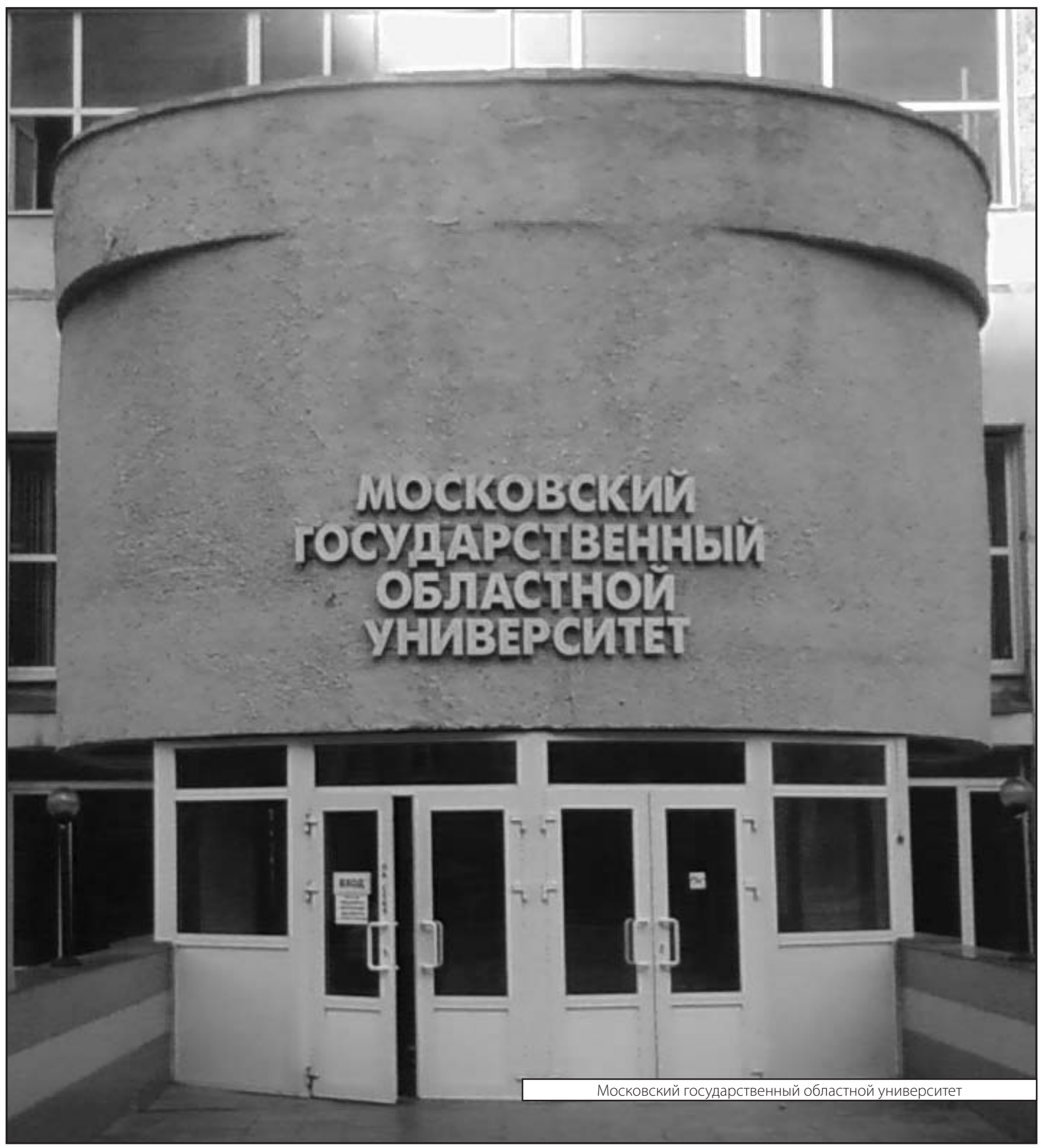

